\title{
Nachtigall in the battle for Lviv Ledge. Structure, tasks, actions
}

Zarys treści: W artykule przedstawiona została wchodząca w skład Wermachtu jednostka Nachtigall oraz jej znaczenie w trakcie bitwy o Lwów. Omówiono jej strukturę dowodzenia oraz rolę i zadania w trakcie walk. Jednostka była badana w kontekście niemieckiej struktury wojskowej od 1941 roku.

Content outline: Thea article discusses the Nachtigall unit, its command structure, and functional characteristics in the advancing Wehrmacht. It also covers Nachtigall's purpose and tasks during the battles for Lviv. The unit is studied in the context of the German military structure as of 1941.

Słowa kluczowe: Batalion Nachtigall, OUN-B, Wehrmacht, Roman Szuchewycz, Friedrich Heinz, III Rzesza, bitwa o Lwów 1941, II wojna światowa

Keywords: Nachtigall Battalion, OUN-B, Wehrmacht, Roman Shukhevych, Friedrich Heinz, Third Reich, the battle for Lviv ledge 1941, Lviv

Nachtigall was a military unit formed in May 1941 at the Wehrmacht training camp near the town of Neuhammer [now Świętoszów]. It was an element of a larger military cooperation project between the "revolutionary" faction of the Organization of Ukrainian Nationalists known as the OUN-B (or OUN-R for "revolutionary") and the armed forces of the German Reich. There were around 350 people in the unit, mainly members of the OUN-B. As a part of a larger battle group [Kampfgruppe], the unit participated in the initial phase of Operation Barbarossa, deployed with the advancing Wehrmacht to Lviv, Zolochiv, Proskuriv (Khmelnytsky) and Vinnytsia. It was sent away from the front line on August 13, 1941 under the suspicion of disloyalty and transformed into Schutzmannschaft Battalion 201 as an auxiliary police unit. Earlier, the members 
of the unit had been involved in mass-scale anti-Jewish violence in Lviv, Zolochiv and Ternopil. ${ }^{1}$

However, despite the large amount of literature that refers to various aspects of Nichtigall's activity, one cannot clearly answer three basic questions: What was Nachtigall at the beginning of Operation Barbarossa? To what extent did it fit into the structure of the attacking forces of the Third Reich? Whose direct orders were executed - those of Ukrainian or German officers?

It is difficult to answer these questions because historiography focuses mainly on more specific issues - either the historical background of the unit's creation or its subsequent actions on the Eastern Front and reformatting it into the 201st Battalion of the Security Police, the future commanders of the OUN-UPA. What remains in the shadows is the short period in the middle, namely the time between the formation of Nachtigall and the capturing of Lviv. A precise study of the time from the beginning of the unit's formation in March 1941 to the end of the battle for the Lviv Ledge (June 30) can help to answer these questions. We need to consider the military affiliation, structure, and main actions of Nachtigall at the beginning of the German occupation of Lviv and to analyze its goals, objectives, and interactions with the local population during this period. Such a focus will help to illuminate one of the most debated events, namely the course of mass violence in Lviv from late June until early July 1941, mainly the anti-Jewish violence on June 30-July 2, 1941, with Nachtigall soldiers considered one the perpetrators.

The goal of this study is to investigate the command structure and functional features of the Nachtigall unit with all possible precision, as well as its role in battle and the seizure of Lviv. Its research base are original documents: orders, instructions and reports now located in the Bundesarchiv in Freiburg. High reliability and low level of manipulability of this collection of sources should be emphasized. The documents were produced during the days of the Wehrmacht strike in the area of Lviv; in addition, they had an operational character and were never meant to be seen by the public. A second important set of sources are protocols from post-war interrogations of OUN members and German administration officiaries (Oleksandr Lutskyi, Alfons Paulus and Alfred Bisanz) produced by the Soviet state security institutions, preserved at the SBU Archive in Kyiv. Those sources require much more in-depth analysis and validation; still, they serve an important complementary function.

Based on these documents, one can reconstruct Nachtigall's actions in the period from May to June 30, 1941. The documents also allow us to better analyze the sources written from a personal perspective, which are filled with inaccuracies

${ }^{1}$ K. Struve, Deutsche Herrschaft, ukrainischer Nationalismus, antijüdische Gewalt. Der Sommer 1941 in der Westukraine, Berlin, 2015; D. Schenk, Noc morderców: kaźń polskich profesorów we Lwowie i holokaust w Galicji Wschodniej, Kraków, 2011; H. Raschhofer, Der Fall Oberländer, Tübingen, 1962, p. 55. 
and opinionated interpretations of the events associated with the entry of the unit into the city.

I deliberately limit the period to be researched until the dawn of June 30, 1941. This will fill in the aforementioned gaps and give answers to the three following questions from the perspective of military history: 1) What was the military function of the battalion? 2) What was its command structure? 3) What was its role in the military action at dawn of June 30 ? Altogether, the goal is to "set up the scene" for this "group of actors" in order to analyze and research waves of massive anti-Jewish violence in Lviv in early July 1941.

\section{Historiographical debates}

Nachtigall is an important factor in several historiographical debates about the significance of Ukrainian nationalism in the Second World War. In particular, the historiography of the Ukrainian liberation movement is represented predominantly by Ukrainian historians, among others Andrii Bolianovskyi or Ivan Patryliak. They consider Nachtigall in the context of the OUN-B attempts to create an army for a stateless nation. Historians of the Holocaust, on the other hand, analyze Nachtigall in the context of its participation in the murder of Jews (Hannes Heer, Dieter Schenk). In the historiography of the Second World War, Nachtigall appears in the context of military cooperation with the German Reich.

Only one large-scale study of anti-Jewish violence during the Wehrmacht's attack in Ukraine in the summer of 1941, authored by Kai Struve, devotes a sub-section to Nachtigall. ${ }^{2}$ This state of research determines our comprehensive consideration of historiography.

The topic emerged in public debate during the Cold War. In 1953, Theodor Oberländer, an officer of Abwehrstelle Krakau and one of Nachtigall's curators, was appointed Federal Minister for Migration, Refugees and Victims of War of the Federal Republic of Germany (1953-1960). In 1960, the Soviet leadership saw the opportunity to reveal Oberländer's past. This was meant to discredit German Chancellor Konrad Adenauer and his Christian Democratic Union, of which Oberländer was a member. Concomitantly, the case was used against the Ukrainian nationalist organizations in the diaspora, where the OUN-B was the most active. ${ }^{3}$

\footnotetext{
${ }^{2}$ K. Struve, “'Nachtigall' und 'Roland," in: id., Deutsche Herrschaft.

3 Andriy Bolyanovsky devoted a special chapter in his research to uncovering the work of the USSR and the GDR special services on the collection and fabrication of materials about the crimes of Nachtigall and Theodor Oberländer in the summer of 1941. A. Bolianovskyi, "Sprava proty Teodora Oberlendera i batal'ionu "Nakhtigal'» u SRSR: fal'syfikatsia dokaziv," in: id., Ubyvstvo pol's'kykh uchenykh u L'vovi v lypni 1941 roku: fakty, mify, rozsliduvannia, Lviv, 2011, pp. 49-69.
} 
The Nachtigall ethos did indeed play an important part in the post-war Ukrainian political émigré circles, especially among the supporters of the OUN-B, as most of Nachtigall soldiers and commanders subsequently became important leaders of the Ukrainian Insurgent Army (UPA), which fought against the German and Soviet occupations from 1942 to 1956 and against Polish underground and population from 1942 to 1945 . The organization was effectively a training platform for the anti-Soviet underground. Among others, in 1945 Nachtigall member Yurii Lopatynskyi, as a Provid courier of Ukrainian Supreme Liberation Council $(U H V R)^{4}$ and a member of the UPA's Main Military Staff, held talks with the command of the Polish Home Army regarding a post-war truce and PolishUkrainian demarcation line. Other former Nachtigall members included Vasyl Sydor (1944-1949), commander of the UPA operational group-West, Deputy Chief Commander of the UPA; Volodymyr Pavlyk - Chief of Staff of the "Sian" Military District of the UPA, ${ }^{5}$ as well as Oleksandr Lutskyi, ${ }^{6}$ Vasyl Brylevskyi, ${ }^{7}$ Ostap Lynda, ${ }^{8}$ and Mykola Levytskyi. ${ }^{9}$ The most important Nachtigall captain was Roman Shukhevych. He was named Deputy Minister of Defense in Yaroslav Stetsko's Ukrainian State Government (June 30, 1941). He was the UPA's Chief Commander from 1943 to 1950. These politicians and militaries led Ukrainian anti-Soviet and anti-German resistance. But after the Second World War, these structures transformed into an effective anti-Soviet independence movement. Thus, attempt to impartially research their activities were and still are complicated by ideological and political factors.

Polar arguments about Nachtigall's activities are reflected in historiography, starting with the idea of the unit's autonomy within the Wehrmacht and full accountability to the OUN-B, presented in the collected memoirs of Nachtigall

${ }^{4}$ Ukrainian Supreme Liberation Council (Ukrayins 'ka golovna vy 'zvol'na rada) - established in July 1944 on the basis of the OUN-B with the purpose of uniting Ukrainian anti-Soviet and anti-German parties of various political leanings.

5 Volodymyr Pavlyk ("Irka," "Pik") - deputy commander and Chief of Staff of WO "Sian" in the initial period of its operation, from May to December 1944. (Moroz W., Wowk O. (ed.), Litopys UPA. Nowa serija, vol. 12: Wojenna Okruha UPA „Buh”. Dokumenty i materialy 1943-1952, Knyha 1, Kyiv-Toronto, 2009, pp. 639, 665).

6 Oleksandr Lutskyi ("Dovbnia," "Bohun," "Marko," "Berkut," "Bohdan," “Andriienko," "Klymenko," "Bodnar"), 1910-1946 - one of the organizers and commanders of the Ukrainian Insurgent Army. OUN Stanislav District Referent in 1933. Imprisoned for his involvement in assassination attempts of the Polish Republic authorities from September 1933 to the beginning of 1938. Commanded of the UPA-West group ("West-Carpathians") from 1943 to September 1944. Member of the OUN-B leadership from October 1943 to March 1944. On January 29, 1945, he was captured by the People's Commissariat of State Security. Executed in Kyiv in 1946.

7 Vasyl Brylevsky ("Borovyi," "Bosyi"), 1915-1945 - UPA major, commander of the detachment in "Zagrava" military district, head of the training department of the UPA-West.

${ }^{8}$ Ostap Lynda ("Yarema"), 1913-1944 - commander of the "Bug" UPA Military District.

9 Mykola Levytskyy ("Makarenko," "Slavuta," "Mikado"), 1914-1944 - Chief of Staff of the "Zagrava" Military District in 1943. 
and Roland combatants, ${ }^{10}$ all the way to the claim that the unit was given a special task from Wehrmacht leadership to incite anti-Jewish violence, suggested in the article by Hannes Heer. ${ }^{11}$

The research and description of the political, social, and military significance of the Nachtigall Battalion at the beginning of the Second World War was actively conducted by the leaders of the OUN themselves and by those involved in the events, including Roman Ilnytskyi (Deputy Minister of National Economy of the Ukrainian State Board, and since 1957, Head of the Organization of Ukrainian Nationalists in exile). In his two-volume work Germany and Ukraine 1934-1945 (Deutschland und die Ukraine 1934-1945) published at the Munich Institute of Eastern Europe in 1957, he introduces a broad excurse to the history of "Ukrainian question" since Hitler's rise to power, and the vision of Ukrainian future developed by German Reich leaders and Ukrainian irredentist circles.

A separate chapter is devoted to the Ukrainian Legion within Wehrmacht. In this section of the book, the author expounds on the goals, objectives, and conditions for establishing the OUN's battalions - Nachtigall and Roland. Analyzing the process of the Legion's creation, Ilnytskyi stresses the importance of the demands which Ukrainian nationalists made and the German side allegedly agreed to and committed itself to meet. In particular, it was the OUN leadership and not the Germans who were responsible for the recruitment and formation of the DUN. Therefore, the political control over military action was put on the OUN-B leadership. The main task of the unit was the fight for the Ukrainian Independent State, where the German leaders had limited leadership responsibilities in terms of training and army routine. Also, the members of the DUN did not have to swear a German oath. ${ }^{12}$

Although these claims coincide with the general pattern of militants' recollections and the political propaganda of the OUN-B, the book does not cite any documents. Instead, Ilnytskyi refers to the preface to the memoir collection titled Druzhyny Ukrajinskyh Nationalistiv... (1953), which explains that the list was not signed by anyone, but simply handed over to the chynnyky by the Wehrmacht, which was interested in creating the units and obliged to adhere to the demands. ${ }^{13}$ However, I have been not able to find the original memorandum; it is also clear that it could not have been officially signed by any government or military official of the Third Reich. Another questionable issue is the term Druzyny Ukrainskyh Nazionalistiv (DUN) - it does not appear in contemporary documents from 1941. I assume that this term was coined by the OUN-B after the war. In the documents

10 Druzhyny Ukrains'kykh Natsionalistiv (DUN) u 1941-1942 rr, vol. 13, Miunkhen, 1954.

${ }^{11}$ H. Heer, "Einübung in den Holocaust: Lemberg Juni/Juli 1941," Zeitschrift Für Geschichtswissenschaft, 49 (5) (2001), pp. 409-427.

12 R. Ilnytzkyi, Deutschland und die Ukraine, 1934-1945 Tatsachen europ. Ostpolitik; ein Vorbericht, vol. 2, München, 1955, p. 140.

${ }^{13}$ Druzhyny Ukrains'kykh, p. 5. 
from the era, we only find such terms as "Ukrainian military legion," "Yevhen Konovalets Legion," and "Bandera legion." 14

An important contribution to the research of Nachtigall's role in anti-Jewish violence of summer 1941 came in the form of studies which followed the exhibition The War for Destruction. Wehrmacht Crimes of 1941-1944, opened in March 1995 under the curatorship of Hannes Heer, an independent historian and writer from Hamburg. The exhibition sparked off an intense debate in the German society and academic circles. In my opinion, it is worth considering this exhibition in more detail, as it serves as a good example of how delicate this subject is in the public opinion. The event demonstrated the importance of careful selection of materials and arguments to cover the subject matter. It also showed how insufficient understanding of military issues can lead to inaccurate conclusions.

The argument presented at the exhibition was constructed around three thematic examples: the detention of Jewish men as "hostages" during 1941 as protection against partisans, followed by their murder; the offensive of the German 6th Army through Ukraine in the summer and autumn of 1941, providing active assistance to SS Einsatzgruppen C responsible for the mass genocide of Jews; the unreasonable "racial war" against the Jews and "Slavic Untermenschen" that the Wehrmacht incited from the first day of Belarus occupation; the responsibility of the German army for the planned mass killings of hundreds of thousands of Soviet prisoners of war. ${ }^{15}$

An important element of the exhibition were photos of the murdered Jewish inhabitants of Zolochiv and Ternopil. The accompanying captions claimed that they had been killed by members of the German army. However, in his 1999 article Photos of an Exhibition. Critical Remarks to the Exhibition "The War for Destruction, Wehrmacht Crimes of 1941-1944," Bogdan Musiał pointed out that some of the photos in fact depicted victims of NKVD killings. ${ }^{16}$ Due to numerous critical voices from other historians, the exhibition was temporarily closed and a special international commission of experts was formed to carry out a separate study and analysis of the presented material.

In November 2000, the commission, one of whose members was Omer Bartov, published a balanced conclusion to its research, recognizing that part of the public criticism was justified. Among the acknowledged inaccuracies was the assertion that parts of the 6th Army were passing through Ternopil and committing

${ }^{14}$ O. Dziuban, (ed.), Ukrainske derzhavotvorennia. Akt 30 czerwnia 1941. Zbirnyk dokumentiw ta materialiw, Lviv-Kyiv, 2001, p. 94.

${ }^{15}$ H. Heer, "The Head of Medusa: The Controversy Surrounding the Exhibition 'War of Annihilation: Crimes of the Wehrmacht, 1941 to 1944,"' in: The Discursive Construction of History: Remembering the Wehrmacht's War of Annihilation, London, 2008, p. 227.

${ }^{16}$ B. Musial, “Bilder einer Ausstellung. Kritische Anmerkungen zur Wanderausstellung „Vernichtungskrieg. Verbrechen der Wehrmacht 1941 bis 1944," Vierteljahrshefte Für Zeitgeschichte, 47 (1999), pp. 563-591. 
war crimes in the summer of 1941, and that the SS-Infanterie-Division (mot.) "Wiking" was not in fact part of the 6th Army (6. Armee), but XIV Army Corps (mot.) of Panzer Group 1 (Panzer Gruppe 1). ${ }^{17}$ The Hamburg Institute for Social Studies dismissed Hannes Heer as the exhibition's curator. In November 2001, after further research and refinement, the director of the institute re-opened the exhibition with the corrected title Crimes of the Wehrmacht: Measures of the War for Destruction, 1941-1944.

Heer published an article on pogroms and the extermination of Jews in Lviv at the beginning of the German-Soviet War. According to him, the main culprit of the violence was Colonel Karl Wintergerst, the military commandant of Lviv, who was in command of all the military units that were stationed in the city at that time. ${ }^{18}$ He claimed that Nachtigall had a special task assigned by the XVII Army Corps: to coordinate anti-Jewish actions, masking them under so-called "self-purification actions" (Selbstreinigugsaktion), which the leadership of the German Reich's Ostministerium planned to use as anti-Bolshevik propaganda. However, the claim about Nachtigall being specifically ordered to appear in the city is unsubstantiated. The three Ukrainian companies incorporated into "Battle Group Heinz" (Kampfgruppe Heinz) had no operational independence.

At the other extreme of the interpretation of those events, we find the work of Ivan Patrylyak, who criticizes the narrative about the involvement of Nachtigall in the murder of Lviv scholars and in anti-Jewish violence. According to him, the tale was spun by Soviet historians and special intelligence services. He also analyzes in detail the uprising of Ukrainian nationalists in the territory of Western Ukraine/Soviet occupation zone of Lviv in the rear of the Red Army immediately after the war began on June 22, 1941, with particular attention to the uprising in Lviv between June 24 and $28 .{ }^{19}$

However, when it comes to the formation, structure, and command of Nachtigall, his book has many inaccuracies. Among others, there is a story about the reorganization of Nachtigall in Hrymailiv and the transfer of command to Captain Heinz. ${ }^{20}$ At that time, Friedrich Wilhelm Heinz was a major. He had commanded the group which included three companies of Nachtigall from the very beginning of the German-Soviet War. Patrylyak also mistakenly refers to Heinz as the military commandant of the city in the first days of the Lviv occupation. ${ }^{21}$ Heinz was never the commandant; by order of June 29, this function was held by Colonel Karl Wintergerst. When it comes to company commanders, there is

17 O. Bartov et al., Bericht der Kommission zur Überprüfung der Ausstellung „Vernichtungskrieg. Verbrechen der Wehrmacht 1941 bis 1944, s.l., 2000, http://www.verbrechen-der-wehrmacht.de/ pdf/bericht_kommission.pdf (accessed: 10 May 2019), p. 48.

${ }_{18}$ Heer, Einübung, p. 421.

19 I. Patryliak, Vijs'kova diial'nist' OUN-B u 1940-1942 rr, Kyiv, 2004, pp. 321- 367.

20 Ibid., p. 307

${ }^{21}$ Ibid., p. 332 
a confusion with German officers. Thus, Patrylak repeats a mistake from Andriy Bolyanovsky's research into Ukrainian military formations in the German armed forces, dividing one person, Erwein von Thun und Hohenstein, into two different officers, "the first being Erwein von Thun, the other Hohenstein." 22

In describing the military operations of Nachtigall in Lviv, Patrylyak relies on the memoirs of Myroslav Kalba. Kalba's work was undoubtedly important in organizing the memories of the combatants and reconstructing the history of the unit. However, in my opinion, his memoirs should not be used for the analysis of Nachtigall's actions during the first days of the German-Soviet War. Kalba was not a participant of the events: on June 24, 1941, he had been sent from Yaroslav to Krakow for medical treatment, and only managed to reach Lviv on July $4 .{ }^{2324}$

\section{Creation, training, command structure}

To clarify the status of Nachtigall, we must have a clear picture of the overall strategic situation at the time. An active struggle of intelligence services and preparations for the war had begun long before Operation Barbarossa and indeed long before the beginning of the Second World War. The Ukrainian question and cooperation with Ukrainian political circles in Europe were an important part in the work of the intelligence agencies of Berlin and Moscow. ${ }^{25}$ Both the German military intelligence (Abwehr) and the political and civil apparatus of oppression (Reich Main Security Office - RSHA) lacked confidence in the Ukrainian irredentist organizations operating on the territory of the Third Reich. According to their estimates, as of 1940, up to forty percent of members of the Organization of Ukrainian Nationalists were collaborating with the NKVD (People's Commissariat

22 Ibid., p. 282; A. Bolianovskyi, Ukrains'ki vijs'kovi formuvannia v zbrojnykh sylakh Nimechchyny: (1939-1945), Lviv, 2003, p. 57. The mistake may have been caused by the adapted translation of Heinz's interrogation during the investigation of the Oberländer case contained in the collection «Nakhtihal'» (Kurin' Dun) u svitli faktiv i dokumentiv edited by Myroslav Kalba in 1984. "I also ordered that one of the SOTNIA commanders be my personal comrade, the former captain of the Imperial Austria, Erwin Count von Thun, and the second - Hohenstein. Count Thun was an Austrian aristocrat [...].” M. Kalba (ed.), «Nakhtihal'» (Kurin' Dun) u svitli faktiv i dokumentiv, Denver, 1984, p. 112.

${ }^{23}$ M. Kalba, "Nakhtigal," in: U lavakh druzhynnykiv: spohady uchasnykiv (Material zibrav i vporiadkuvav M. Kal'ba), Denver, 1982, pp. 27-28.

${ }^{24}$ A similar mistake was also made by Kai Struve in regard to Myroslav Kalba's recollections about the Wehrmacht's occupation of Lviv on June 30. Struve, op. cit., p. 356.

25 This activity is broadly reflected in the related archives of the Security Service of Ukraine and the archive of civilian central authorities of the German Reich at Berlin-Lichterfelde; Галузевий Державний Архів Служби Безпеки України. (ГДА СБУ), Ф 16., оп. 1. с. 511 (Секретаріат ГПУ-КГБ УРСР). Bundesarchiv, Berlin-Lichterfelde (BA-BL), R 43 - II Akt. 1500. Reichskanzlei. Dr. Lammers. 
for Internal Affairs). ${ }^{26}$ Therefore, Berlin chose to rely not on the organization as a whole, but on selected individuals, such us Richard Jary (Riko Jary) - a double agent of the Abwehr and the OUN-B. ${ }^{27}$

Unsurprisingly, the Wehrmacht and the OUN-B leadership differed in their understanding of the tasks of the Ukrainian units under German command. For the OUN-B, which lobbied for the creation of the "Yevhen Konovalets Legion"28 and was engaged in direct recruitment of soldiers, the detachment was envisioned as the core of a Ukrainian Army. In particular, Ivan Klymiv (Lehenda), ${ }^{29}$ appointed as a Chief Commander of the Ukrainian National Revolutionary Army (Ukrayins 'ka nacional 'na revolyucijna armiya - UNRA) at the Yaroslav Stetsko Government, issued a public statement on the creation and tasks of UNRA on August 1, 1941, referring to the "Nachtigall" and "Roland" Battalions as "Ukrainian Military Legion," a separate structure that "operates under the sole guidance of the OUN and its leader Stepan Bandera." 30

Ukrainian historians agree that there was an informal agreement between the leaders of the OUN-B and Abwehr officers on the conditions under which the two units would be formed. This claim is supported by further public rhetoric of the OUN.

However, for the leadership of the Wehrmacht, in particular the Abwehr officers, the Nachtigall unit was regarded as a "Sonderformation" - a special formation with clearly defined tactical objectives, operating within a larger German unit. ${ }^{31}$ Among these objectives were anti-diversion and initial protection of strategic

${ }^{26}$ ГДА СБУ, Ф16.оп1. с.511 ap. 17 (Секретаріат ГПУ-КГБ УРСР).

${ }^{27}$ R. Torzecki, Polacy i Ukraincy. Sprawa ukraińska w czasie II wojny światowej na terenie II Rzeczypospolitej, Warszawa, 1993, p. 63.

${ }^{28}$ The author considers it expedient to refrain from the use of the term Durzhyny Ukraïns'kykh natsionalistiv, which is how it is most frequently referred to Ukrainian studies. The best known example can be found in Orhanizacija ukrajinśkych nacionalistiw i Ukrajinśka powstanśka armija. Fachowyj wysnowok roboczoji hrupy istorykiw pry Uriadowij komisji $z$ wywczennia dijalnosti OUN $i$ UPA, Kyiv, 2005, p. 7; G. Rossoliński-Liebe, Stepan Bandera. The Life and Afterlife of a Ukrainian Nationalist: Fascism, Genocide, and Cult, Stuttgart, 2014, p. 174. This term does

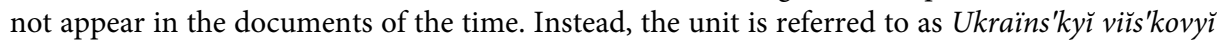
lehion or Lehion imeni Ievhena Konoval'tsia.

${ }^{29}$ Ivan Klymiv ("Aridnyk," "Kuliba," "Marmash," "Lehenda") - regional leader of the OUN in Western Ukraine (1940-41). Minister of Political Coordination of the Ukrainian State Government in Lviv. Member of the Main Board of the OUN-B (since 1941) and its organizational referent (1941-42), military referent (1942). Arrested and killed by the Gestapo in Lviv on December 4, 1942.

${ }^{30}$ Центральний державний архів вищих органів влади та управління України (ЦДАВОВ), Ф. 3833. оп. 1, f. 45, Copy of the letter of the regional leader of the OUN: (Ivan) Lehenda - to the head of OUN's Provid on organizational work in the western Ukrainian lands, Appeal of the First Commander of the Ukrainian National Revolutionary Army.

${ }^{31}$ Bundesarchiv-Militärarchiv, Freiburg im Breisgau (BA-MA) RH 20-17/276, Ansatz eines Btl. des Rgt. z.b.V. 800 in in A.O.K. 17 Führungsabteilung Tätigkeitsberichte Ic/A.O. Anlage Erlassene Befehle Grundsatz. Schriftverkhr vom 16.03 - 12.12.41. 
objects, such as ammunition depots, radio stations, railway junctions, etc. In principle, units of this type played an important role in the Blitzkrieg and were used to capture, retain and prevent diversion or destruction of infrastructure vital to the rapid advance of motorized units into hostile territory. However, the low motorization level of Nachtigall hinted at its low military priority. The memoirs of Theodor Korinets, for example, mention that the unit moved on foot from the Soviet border on the San River to the Yaniv forest near Lviv. ${ }^{32}$ This was typical for the units of the "second line."

The formation of the battalion began in March 1941 with the creation of the military headquarters of the Legion by the leadership of the OUN-B. The mobilization department was headed by Mykola Lebed, assisted by Oleksandr Lutskyi [Ołeksandr Łućkyj]. The work was organized the following way: Lutskyi and Yurii Lopatynskyi [Jurij Łopatynśkyj] received applications from members and sympathizers of the OUN on behalf of the Provid and assessed their suitability for military service. Those applications were passed on to Volodymyr Fedak, who handed over lists of proposed recruits to the Germans. The selected candidates were then sent to training camps. ${ }^{33}$ The Wehrmacht side was represented by Abwehrstelle Krakau under the direction of Major Ernst zu Eickern. The military training was conducted on the level of companies (Kompanien). According to Lutskyi, approximately 100 men were sent to a camp in the Lemko village of Krynica Wieś (now a district of Krynica), another 100 were divided between Dukla and Lemko villages of Barwinek (Барвінок) and Komańcza (Команча) in the southern part of the General Government, and 150 were sent further to Brandenburg. Their preparations took the form of conventional infantry training. ${ }^{34}$ In May, all three groups were brought to a camp near the town of Neuhammer (Świętoszów) for further combat alignment and integration. They were joined by Provid members arriving from Krakow, selected as the Ukrainian commanders of the battalion, among them Shuchevych and Lutskyi.

On May 25, 1941, a few weeks before the beginning of Operation Barbarossa, the Nachtigall special formation was assigned to participate in the operation of capturing and securing the existing infrastructure in Lviv and its surrounding territories. ${ }^{35}$ According to the plans of the High Command, no propaganda,

32 Testimony about Theodore Korinets and his activities in UVO, OUN, Nachtigall and Roland battalions for 1927-1946. Архів центру дослідження визвольного Руху АЦДВР, Ф. 11. Т. 30.

33 Excerpt from the interrogation protocol of the accused Lutskyi Oleksandr Andreevich from July 31 and August 1, 1945, Kiev. ГДА-СБУ. Ф. 13. Спр. 372. Т. 38. Ар. 288

34 Handwritten testimony of prisoner of war Paulus Alphonse, sergeant-major of the German army, about the activities of the Abwehr point in Krakow written on September 24-29, 1945. ГДА-СБУ. Ф. 13 Спр. 372. Т. 37. Арк. 197-214.

35 BA-MA RH 20-17/276, Ansatz eines Btl. des Rgt. z.b.V. 800 in in A.O.K. 17 Führungsabteilung Tätigkeitsberichte Ic/A.O. Anlage Erlassene Befehle Grundsatz . Schriftverkhr vom 16.03 -12.12 .41 . 
political or other roles were foreseen in the activity of the unit during the military action.

This assignment was disclosed neither to the soldiers in the unit nor to their Ukrainian leaders. The Ukrainian men conscripted into the legion were told that they would undergo military training courses for the OUN. In the interrogation protocol from August 1, 1945 in Kyiv, Lutskyi said: "Even I was officially assured by [Mykola] Lebed in early June 1941 that we were sending these people to military training, and only in early June a German officer, Count Thun, told me in a conversation that in the near future Germany would attack the Soviet Union..." 36

After assembling all three companies (Sotni) in one camp, the Nachtigall unit was formed. The command officer of the entire battalion was Hans-Albrecht Herzner. A German officer was assigned to each company: 1st - Erwin von Thun und Hohenstein, 2nd - Friedrich Middelhauve and 3rd - Schiller (unfortunately it has not been possible to find his first name). The Germans apparently broke the earlier promise that the commanders would be Ukrainians selected from among the OUN-B leadership. According to Lutskyi, after arriving in Neuhammer, the putative Ukrainian commanders were enlisted as ordinary soldiers. Only in the second half of June 1941 were they appointed as squad leaders. Although this information contradicts the memoirs of Nachtigall combatants and the subsequent historiography, in my opinion it is accurate. German military documents mention no Ukrainian officers, only Germans. In photographs of Nachtigall soldiers taken in June-July 1941, the members of the proposed OUN-leadership Shukhevych, Lutskyi, Lopatynskyi and others - do not have officer insignia on their Wehrmacht uniforms.

The only found document to state that Roman Shukhevych completed his officer's courses and served as a captain in the German army is the interrogation protocol of Alfred Bisantz from November 23, 1949. ${ }^{37}$ However, this particular source abounds in inaccuracies and distortions. In particular, Senior Operations Officer Kuznetsov asks Bisantz several times about the Abwehr's "High School of Intelligence in Brandenburg," in which Shukhevych allegedly had been studying since the beginning of $1941 .^{38}$ No such institution seems to have existed. In any case, Shukhevych could not have been present at the facility all this time given his organizational duties for the OUN-B in Krakow. Most likely, Bisantz was referring to four-week Abwehr preparatory courses for saboteurs, which were attended by Ukrainians selected from among the members and sympathizers of the OUN.

Although their company commanders were German officers, Nachtigall soldiers perceived the members of the OUN's Provid as their leaders and addressed

\footnotetext{
36 Excerpt from the interrogation protocol of the accused Lutskyi Oleksandr Andreevich from July 31 and August 1, 1945, Kiev. ГДА-СБУ. Ф. 13. Спр. 372. Т. 38. Ар. 288.

37 Record of the interrogation of convicted Bizantz Alfred Ioganivich, from November 23, 1949. ГДА-СБУ. Ф. 65.Спр. С. - 7448 Арк. 15 - 22.

38 Ibid.
} 
them according to their own titles and ranks. It is for this reason that Roman Shukhevych is called the commander of the Nachtigall Battalion in all memoirs of Nachtigall's combatants. In reality, he and the other Ukrainians took care of the technical execution of German officers' orders.

The German officers were responsible for the actions of their combat units. This was due to the German tradition of troop command (Auftragstaktik), in which even the commanders of small units were given operational and tactical independence - each lieutenant was assigned tasks appropriate for the character of his unit and was given freedom to decide how they should be performed based on combat circumstances right on the spot. ${ }^{39}$

As for the uniform and distinguishing marks used by the division, it was the standard gray (feldgrau) Wehrmacht uniform of 1936 (the so-called M 36). According to photographs and memoirs, a small blue-and-yellow rank slide, up to 4 centimeters long, was put on the shoulder mark. ${ }^{40}$ No other special marks were used. This fact, insignificant at first glance, is indeed very important when analyzing the sources which include personal accounts of violence (eyewitness testimonies, diaries, memoirs, etc.).

The training of the Nachtigall and Roland units was conducted under the umbrella of Training Regiment Brandenburg 800 (Lehrregiment Brandenburg $z . b . V .800$ ), headed by Erwin von Lahousen, Chief of the Second Department of the Abwehr. It consisted of three battalions and five special companies (Kompanien). Each of the three battalions consisted of four companies. The first battalion, under the command of Major Hans Friedrich Heinz, ${ }^{41}$ was deployed to Zakopane on April 28 (southern General Government, now Poland), where it was joined by the "Nachtigall" Special Formation (Sonderformation "Nachtigall").

By order of June 12, Nachtigall was subordinated to the Brandenburg regiment. A bit later, Heinz received an order to relocate the second and fourth companies, along with Nachtigall, to Przemyśl. Thus was formed the so-called "Battle Group Heinz" (Kampfgruppe Heinz), which was supposed to be one of the first units to enter Lviv. In military documents, the combat group is called Battalion 800 . This is due to the fact that Heinz was the commander of the I Battalion of the regiment, which was stationed directly in the city of Brandenburg. In the initial phase of Operation Barbarossa, only 2nd and 4th Companies were under Heinz's command. ${ }^{42}$

39 T. Ripley, The Wehrmacht: the German Army in World War II, 1939-1945, New York, 2003, pp. 215-216.

40 Y. Lopatynskyi, “Hrupa pivnich t. zv. Nakhtigal," Svoboda Ukrainian Daily (15 June 1960), p. 2.

${ }^{41}$ F. Kurowski, Baulehr-Bataillon 800 z.b.V. Brandenburg: Akce německých komand 1939-1945, Praha, 2006, p. 72.

42 BA-MA RH 20-17/276, Zuteilung des Lehrregts. «Brandenburg» z.b.V. 800 in A.O.K. 17 Führungsabteilung Tätigkeitsberichte Ic/A.O. Anlage Erlassene Befehle Grundsatz . Schriftverkhr vom $16.03-12.12 .41$. 
Despite claims to the contrary found in memoirs of Nachtigall combatants, it was not an independent military unit. It was directly subordinate to the First Mountain Rifle Division of the Wehrmacht. ${ }^{43}$ The three Ukrainian companies were part of this larger tactical unit together with two other German companies and a motorcycle unit (Kradschützen). In the reports from the battlefield, the leadership of the battle group specifically referred to Nachtigall subsections as the Ukrainian companies (U-Kompanien) or mixed companies (gemischte Kompanien). Nachtigall was not referred to as a separate battalion.

\section{Battle for the Lviv Ledge}

According to plans of Operation Barbarossa, Lviv was in the operational zone of the 49th Mountain Corps Command (Generalkommando XXXXIX. Gebirgskorps) and 17th Army (17. Armee) under the command of General Carl-Heinrich von Stülpnagel. The battle group was instructed to operate in the interests and subordination of the 1st Mountain Division (1. Gebirgs-Division) under the command of Major-General Hubert Lanz.

Between June 22 and 28, heavy battles were held outside Lviv. The Soviet command assembled a powerful military compound united into the 6th Army under General Ivan Muzychenko. Among others, it incorporated the 4th Mechanized Corps led by General Andrey Vlasov, which included some of the most combat capable units of the Red Army, namely the 8th and 32nd Tank Divisions and 81st Motorized Division. Nachtigall did not take part in direct combat, acting as a second-line formation. At $10 \mathrm{pm}$ on June 28, Kampfgruppe Heinz arrived in the forest near Stradch, 16 kilometres from Lviv. ${ }^{44}$

The final order to seize Lviv (Sonderanweisung "Lemberg") was issued on June 28, at 11:40 am. The order stated that units of Kampfgruppe Heinz should occupy the city center. A special Sicherheitsdienst (SD) group (Sonderkommandos 4b from Einsatzgruppe C) was to operate according to its own special plan, without the participation of troops. ${ }^{45}$ The SD group was neither authorized nor meant to involve troops in its activities. The order also details the classical Wehrmacht scheme for city occupation and ensuring further movement of troops. According to the instructions, the military police unit was to fulfil its special tasks, which typically included monitoring and control of order and discipline among the military personnel.

On June 29, the commander of 49th Mountain Corps (XXXXIX. Gebirgskorps), General Ludwig Kübler, appointed forty-nine-year-old seasoned officer Colonel

${ }^{43}$ Bolianovskyi, Ukrains'ki vijs'kovi.

${ }^{44}$ BA-MA RH 24-49/14, Korps Befehl Nr.18 für die Fortsetzung der Verfolgung am 29.06.1941 (17.00 28.06.1941) in KRIEGESTAGEBUCH NR.3 DES XXXXIX, p. 89.

45 BA-MA RH 24-49/14, Sonderanweisung «Lemberg» in Kriegstagebuch Nr.3 DES XXXXIX, p. 86. 
Karl Wintergerst as the military commandant of Lviv. Among other duties, he was ordered to ensure city security, traffic control, prevent looting among the local population, and prevent any sort of unrests, including those that could be caused by the military. To accomplish these tasks, the commandant of the city was empowered to take even the most rigid measures.

At Wintergerst's disposal were the 132nd Artillery Headquarter (ArtillerieKommandeur 132), Battalion 800 (i.e. Battle Group Heinz), a patrol group, a motorized police battalion, parts of Battalion 760 of Traffic Control, and II Battalion of the 1st Mountain Division. ${ }^{46}$

On the basis of the tasks assigned by the Corps Command to these military units, we can draw five conclusions about the situation as of June 29: 1) The fighting itself was thoroughly planned in accordance with the immediate situation; 2) Each military unit that participated in the operation had its own specific task and function; 3) Interaction of the military with the local population was subject to a specific utilitarian purpose - to ensure order for further movement of the army to the East; 4) The SD group/Einsatzkommando was given carte blanche for its actions in the city, but was not authorized to engage the military personnel; 5) The appointed commandant of Lviv was informed about his duties and specific tasks before the city was captured, and had sufficient means to maintain effective control over Lviv.

In the morning of June 29 , a group of troops was formed in the northwestern offensive position outside Lviv with the order of capturing the city. It consisted of three battalions of the 98th and 99th Regiments of the 1st Mountain Division, 79th Artillery Regiment, and Artillerie-Regimentsstab 501, as well as Battle Group Heinz, which included two German and three "mixed" (Ukrainian) companies with an accompanying motorcycle unit.

At about 1:00 pm, the forces of the 1st, 2nd, and 3rd Battalions of the 98th Regiment of the 1st Mountain Division, under the command of Colonel Egbert Picker, approached the line Rzesna Polska (modern: Ryasne-2)-Briukhovychi. By the end of the day, still on June 29, the regiment reached the borders of Lviv. The forces of the 1st Battalion took positions at Kleparov and Kortumowa Gora, the forces of the 3rd Battalion took Holosko, the 2nd Battalion was entrenched in front of the Zboiska. The headquarters of 79th Mountain Artillery Regiment was located in Ryasne. The companies of Battle Group Heinz were located between the villages of Rzesna Ruska (Ryasne Ruske) and Rzesna Polska (Ryasne Polske). The I, II, and III Battalions of the 99th Regiment under the command of Colonel Hermann Kreß were in the villages of Kozhychi, Karachyniv and Ryasne-Ruske, along with Artillerie-Regimentsstab 501.

Upon reaching this line, the command of the 1st Mountain Division stopped further attack. A special patrol consisting of "Ukrainians in civilian clothes" was

46 BA-MA RH 24-49/14, Befehl fur den Stadtkommandanten von Lemberg in Kriegstagebuch Nr.3 DES XXXXIX. BAMA., pp. 104-105. 
sent to the Lviv city center. The patrol returned at 1:30 am on June 30. It reported that Lviv was protected with some Soviet KV-1 heavy tanks and armored cars. They also informed the command of mass killings of the Ukrainian population. ${ }^{47}$

At 2:30 am on June 30, the companies of Battle Group Heinz started to move in columns in the direction of Lviv, some 500 meters behind the I Battalion of the 99th Mountain Infantry Regiment [I/ Geb.Jäg.Rgt. 99 for short] under the command of Major Josef Fleischmann. Due to the lack of additional directives, the group leaders agreed that the Fleischman group would be moving through the city to the Citadel. ${ }^{48}$ At the same time, the Kampfgruppe Heinz companies moved along Yanovska Street, starting by the railway station, to capture defined objects.

At 3:50 am on June 30, Major Fleischman handed Heinz an order from the division to stop the offensive. However, having learned that there were still some surviving German soldiers and Ukrainians in the burning NKVD prisons (the information came from the Ukrainian soldiers of the Heinz group), Heinz decided to nonetheless move his unit towards St. George's Cathedral (Ukrainian Greek Catholic Sobor sviatoho Yura). Analyzing the reasons for this decision, Heer concludes that Heinz was guided by the real task of the Batalion 800 "to take control of the prison and possibly coordinate anti-Jewish actions." 49 This seems unlikely if we assume that the Wehrmacht command had assigned a special political propaganda role to Nachtigall. In such a case, it would make no sense to attach two additional German companies to the three Ukrainian units within Battle Group Heinz. All these companies continued to move together to the center of Lviv and occupy specific objects.

Heinz himself provided two reasons for ignoring the order in a report written on the following day: 1) He wanted to save German soldiers and Ukrainians, "the relatives of fighters of his group," from being burned alive in prison; 2) He wanted to secure the warehouses and stores "which the crowd and Jews were about to loot." 50

In my opinion, Heinz's orders were guided by conventional military logic, as his unit's priority was to ensure the security of the city's infrastructure facilities (the main of which were the railway station and military warehouses) and counteract potential sabotage. Thus, the two most trusted German companies were

47 BA-MA RH 28-1/23, Gebirgsdivision Ia, Anlage zum KTB-Ost Nr. 1 vom 19.4.-10.8.1941, Bataillon 800, Kommandeur, 1.7.41, "Schlussmeldung über Einnahme Lemberg und vollzogene Objektsicherung."

${ }^{48}$ The main military object of Lviv, located in the center of the city at Kalicza Gora, the citadel is a complex of fortifications built in the 1850s for a potential counteraction to any uprisings in the city. The strategic location allows to effectively control the city center.

${ }^{49}$ Heer, Einübung, 416.

50 BA-MA RH 28-1/23, Gebirgsdivision Ia, Anlage zum KTB-Ost Nr. 1 vom 19.4.-10.8.1941, Bataillon 800, Kommandeur, 1.7.41, „Schlussmeldung über Einnahme Lemberg und vollzogene Objektsicherung." 
sent to these sites, while Ukrainian companies were sent to take positions with a lower priority. ${ }^{17}$

Heinz's decisions were based on intelligence data provided by a special team of his "Ukrainian soldiers" dressed in civilian clothing. It can be assumed that the motivation of Nachtigall leaders to move first to St. George's Cathedral was to ensure the security of Metropolitan Andrey Sheptytsky. In his report, Major Heinz writes that at 4:00 am, his special group found the metropolitan in a building near the burning cathedral. ${ }^{51}$ However, we know that neither St. George's Cathedral itself nor the surrounding buildings were subjected to any hostile action of retreating Soviet forces. Since we have not found any plans or directives for Heinz to move precisely to the cathedral, we can assume that Abwehr officers, acquainted with the political elites of Galicia, perceived Metropolitan Sheptytsky as an important person with whom it was necessary to meet first and provide protection. In combatants' recollections, one can find information that a group of German officers came to St. George Cathedral in the early morning to meet with Metropolitan Sheptytsky. ${ }^{52}$

An important point made in Major Heinz's report is "that the crowds and Jews [a clear anti-Semitic suggestion, often used by Germans as a justification for repressing Jews!] are going to plunder warehouses." He most likely received this information from the aforementioned special reconnaissance team in civilian clothes. However, according to Yevhen Nakonechnyi's memoirs, food supply was partly distributed by the Soviet authorities from the warehouses "so that it would not get into German hands"53 and that there were numerous cases of store and warehouse robberies by local residents (regardless of nationality). Heinz's report, therefore, uncovers his perception of local Jews as looters.

At 4:00 am, the I Battalion of the 99th Mountain Infantry Regiment (I./ Geb. Jäg.Rgt. 99), headed by Major Fleischman, seized the Lviv Citadel on the Vronsky Mountain. ${ }^{54}$ The mountain riflemen then moved into the lower part of Yanovska Street (now Taras Shevchenko Street). This fact is confirmed by the memoirs of Yevhen Nakonechnyi, in which he recalls that before dawn of June 30, him and a small group of his neighbors were observing the intersection of Yanovska and Horodetska streets. There, they noticed soldiers in German uniforms and mountain shoes moving in the direction of the opera house. ${ }^{55}$ Most likely, the

51 BA-MA RH 28-1/23, Gebirgsdivision Ia, Anlage zum KTB-Ost Nr. 1 vom 19.4.-10.8.1941, Bataillon 800, Kommandeur, 1.7.41, „Schlussmeldung über Einnahme Lemberg und vollzogene Objektsicherung."

52 July 1, 1941. An account of the Ukrainian Legion soldier Antin Fedenyszyn on the legion entering Lviv; Dziuban (ed.), op. cit., pp. 95-98.

${ }^{53}$ Y. Nakonechnyi, "Shoa" u L'vovi, 2nd ed., Lviv, 2006, p. 92.

${ }^{54}$ BA-MA RH 28-1/23, Fernmündliche Orientierung des Oberst Winkler durch Div. Kdr. in Gebirgsdivision Ia, Anlage zum KTB-Ost Nr. 1 vom 19.4.-10.8.1941.

55 Nakonechnyi, op. cit., p. 94. 
German mountain riflemen belonged to the 98th Mountain Infantry Regiment (Geb.Jäg.Rgt. 98), whose task was to take the strategic high point of the city the High Castle hill and military buildings beneath it. With simple calculations and taking into account the position of the I Battalion (I./ Geb.Jäg.Rgt. 99) and the units of Kampfgruppe Heinz as of 3:00 am and the distance they covered by 4:00 am, it can be concluded that the Kampfgruppe Heinz units of Battalion 800, including companies of the Nachtigall Battalion, were not the first to enter the central part of the city.

At 4:20 am on 30 June, the second company of Battalion 800 under the command of Captain Hartmann took control of the main train station, the tank repair workshop, and the main warehouse and railway bridges (probably the bridges on the north and southwest of the station).

According to the memoirs of Yurii Lopatynskyi, around 4:30 am a part of his company began to move to St. George's Cathedral, while the other part - in the direction of Lonskoho and Pelchinska streets. ${ }^{56}$ Kostiantyn Talanchuk, a Nachtigall soldier, recalled that after 4:00 am, his entire unit took the shortest and fastest path to St. George's Cathedral, from the upper part of Yanovska Street (Taras Shevchenko) through Bema Street (Benedyktynska), crossing Gorodotska, further to Shpitalna (I assume that the author was mistaken here and actually meant Petro Skarga Street: Ozarkevycha). ${ }^{57}$ Analyzing these two testimonies against the geography of Lviv, namely the closest route to the prison Lonsky Street via the St. George hills, it can be estimated that the entire 1st Company of the Nachtigall Battalion covered the above-mentioned distance between 4:30 and 5:30 am.

At the same time, the 2nd Company of the Nachtigall Battalion, according to Lopatinskyi, went to the City Gas Station (Gazova Street) and the prison in Zamarstyniv (NKVD Prison No. 2 on 9 Zamarstinivska Street). This is confirmed by the Heinz report, stating that the "Rathaus" special group set out to take over and defend the warehouses in the city center and the jail in Kazimierzowska Street (NKVD Prison No. 1, Gorodotska). ${ }^{58}$

Between 5:30 and 6:15 am, the parts of Kampfgruppe Heinz which had advanced the farthest took control of and placed patrols around the Main Post Office (39 Slavskoho St.) and the House of the GPU (i.e. the Regional Directorate of the NKVD, 55 Vitsovskoho St.), where the departmental documents of Soviet security organs were stored; the leather factory (Svitanok, Promyslova St.) and the municipal power station (Persenkivka, Kozelnitska St.), in which they immediately urged workers to repair damaged equipment; as well as the chocolate factory (it is

${ }^{56}$ Lopatynskyi, op. cit., p. 2.

${ }^{57} \mathrm{~K}$. Talanchuk, “«Solovejky» DUNu,” in: U lavakh druzhynnykiv: spohady uchasnykiv (Material zibrav i vporiadkuvav M. Kalba), Denver, 1982, p. 64.

${ }^{58}$ BA-MA RH 28-1/23, Gebirgsdivision Ia, Anlage zum KTB-Ost Nr. 1 vom 19.4.-10.8.1941, Bataillon 800, Kommandeur, 1.7.41, „Schlussmeldung über Einnahme Lemberg und vollzogene Objektsicherung." 
not specified whether it was the "Hazet" Factory on Zavodska Street or "Branka" on Sheptytskych Street; it was most probably the latter because of its immediate vicinity to the railway station). The Arsenal was also seized, with a huge number of weapons found inside ${ }^{59}$; what Heinz likely referred to here were barracks and vehicle stalls on Horodotska Street, where 30 tanks were found, including 12 heavy tanks and one anti-aircraft vehicle. In a separate section, the report mentions the occupation of the freight station (Klepariv railway station), where a "large volume of valuable goods was saved from looters."

At 7:00 am, all of the facilities and warehouses foreseen in the plans were occupied, and security was provided in places where there was a risk of explosions. At 9:00 am, a Soviet militant group with three machine guns attacked the radio transmitting station (Ivan Franko St.). However, soldiers from the 4th Company of Kampfgruppe Heinz were able to withstand the attack and seize a machine gun.

All three companies of the Nachtigall unit were located in the central part of Lviv and in the first days were involved in the protection of urban facilities. Konstantin Talanchuk notes that having been greeted by Metropolitan Andrey Sheptytsky on the square between the cathedral and the metropolitan chambers, his second platoon of the 1st Company of Nachtigall, commanded by Roman Shukhevych, moved to the "Lonskoho Prison" (1 Stepan Bandera St.) to maintain order. ${ }^{60}$ It was the spot where his brother Yuri Shukhevych had been killed. In the afternoon, his unit was replaced by another platoon of the 1st Company and transported to another location.

Having arrived at the new site, Talanchuk managed to obtain a ZIS truck (probably a ZIS 5). Thus, on the evening of June 30, his platoon drove to Temni Valy - Dark Shafts (probably to the building of the Second German Gymnasium [Modern School no. 8, 2 Pidvalna St.] for the night. The 1st company of the Nachtigall Battalion was stationed there until it left Lviv.

We can reconstruct the locations of the Kampfgruppe Heinz units, the I Battalion of the 98th (I./Geb.Jäg.Rgt. 98), and the 99th Mountain Infantry Regiment (Geb. Jäg.Rgt. 99) in Lviv on the morning of June 30, 1941 with high accuracy. All major military and civilian objects and high points in the city center were occupied by those units. As of the morning of June 30, 1941, the city of Lviv was completely under the control of the Wehrmacht. Colonel Wintergerst started to perform his duties as military commandant of Lviv. ${ }^{61}$ The location of the occupied objects allowed the army to observe all events taking place in the city, including any activities of the local population. It also gave the Wehrmacht forces present in

\footnotetext{
59 BA-MA RH 28-1/23, Gebirgsdivision Ia, Anlage zum KTB-Ost Nr. 1 vom 19.4.-10.8.1941, Bataillon 800, Kommandeur, 1.7.41, „Schlussmeldung über Einnahme Lemberg und vollzogene Objektsicherung."

${ }^{60}$ Talanchuk, op. cit., p. 64

${ }^{61}$ Struve, op. cit., p. 256.
} 
Lviv the ability to immediately prevent, stop, and eliminate any manifestations of sabotage, robbery, or violence - but they did nothing to counteract such incidents.

\section{Conclusions}

The research carried out for the present paper refutes the thesis that Nachtigall was an independent military-political unit with its own autonomous Ukrainian commanders and freedom of action in the summer of 1941 and the beginning of the Soviet-German war, not denying the personal loyalty of the soldiers to their OUN fuglemen.

Our findings show that the military structure of the Nachtigall Battalion and its use in the first weeks of the war remained under clear control and accountability to the German command. Nachtigall as a unit did not receive any additional orders with a propaganda purpose during the period under review and acted in accordance with the plans and instructions of Battle Group Heinz (Kampfgruppe Heinz) ${ }^{62}$

In addition, the conclusions drawn from the research allow us to make several contributions to the current state of research. As it transpires from the study, the personnel originally put forward to the OUN as potential leadership of Nachtigall was eventually not appointed by the Germans, and the commanders of the three companies were German officers. Sondergruppe Nachtigall participated in the capturing of Lviv as part of a larger unit together with two German companies. All three companies performed the tasks of army reconnaissance or scouts, like the other companies in Battle Group Heinz from Lehrregiment Brandenburg 800.

The present findings have clarified inaccuracies and errors present in previous historiographic research of Nachtigall. They also improve the understanding of Nachtigall's internal mechanisms and the position of its subunits among the other Wehrmacht troops at the beginning of the German-Soviet war. In a practical sense, this knowledge may help researchers to verify witnesses accounts concerning this military formation and its actions during the summer of 1941.

Future research perspectives lie in moving on from analyzing military units created under the Wehrmacht umbrella (Nachtigall and Roland) exclusively on the basis of Ukrainian narrative sources, such as witness accounts and memoirs, and instead using a broader primary source base, especially documents from German archives.

62 "The soldiers of the [Nachtigall] Battalion are often charged with committing numerous crimes in the city. Certainly, contrary to popular opinion, they are not responsible for the execution of Lviv professors. This crime was committed by a special SS commando. Did they take part in anti-Semitic pogroms? This issue has not yet been resolved," wrote Polish historian Grzegorz Motyka, Ukraińska partyzantka 1942-1960. Działalność Organizacji Ukraińskich Nacjonalistów i Ukraińskiej Powstańczej Armii, Warszawa, 2006, pp. 96-98. 


\section{Abstract}

The article investigates the command structure and functional features of the Nachtigall unit with all possible precision, as well as its role in the battle for and seizure of Lviv. It describes what Nachtigall was at the beginning of Operation Barbarossa, to what extent it fit into the structure of the Third Reich attacking forces, and whose direct orders were executed - those of Ukrainian or German officers. The paper uses the method of "dense description," which forms part of microhistorical research tools. The research is based on Wehrmacht officers' orders, instructions, and reports from the Bundesarchiv in Freiburg. It also makes use of reports from post-war interrogations of OUN members and German administration officials produced by the Soviet state security institutions, which are preserved at the SBU Archive in Kyiv. The article proves that the military structure of the Nachtigall Battalion and its use in the first weeks of the war remained under strict control and accountability to the German command, not Ukrainian nationalists from UON-B. Nachtigall as a unit did not receive any additional orders to fulfil propaganda-related tasks during the period under review and acted in accordance with the plans and instructions of Battle Group Heinz (Kampfgruppe Heinz). In addition, the conclusions drawn from the study allow us to make several contributions to the current state of research. The personnel initially put forward to the OUN as potential leadership of Nachtigall was eventually not appointed by the Germans, and the commanders of the three companies were German officers. The findings have clarified inaccuracies and errors present in previous historiographic research of Nachtigall.

\section{Bibliography}

Bartov O. et al, Bericht der Kommission zur Überprüfung der Ausstellung „Vernichtungskrieg. Verbrechen der Wehrmacht 1941 bis 1944," s.l., 2000.

Bolianovskyi A., Ubyvstvo pol's'kykh uchenykh u L'vovi v lypni 1941 roku: fakty, mify, rozsliduvannia, Lviv, 2011.

Bolianovskyi A, Ukrains'ki vijs'kovi formuvannia v zbrojnykh sylakh Nimechchyny: (1939-1945), Lviv, 2003.

Druzhyny Ukrains'kykh Natsionalistiv (DUN) u 1941-1942 rr, vol. 13, Miunkhen, 1954.

Dziuban O. (ed.), Ukrainske derzhavotvorennia. Akt 30 czerwnia 1941. Zbirnyk dokumentiw ta materialiw, Lviv-Kyiv, 2001.

Heer H., "Einübung in den Holocaust: Lemberg Juni/Juli 1941," Zeitschrift Für Geschichtswissenschaft, 49 (5) (2001), pp. 409-427.

Heer H., "The Head of Medusa: The Controversy Surrounding the Exhibition 'War of Annihilation: Crimes of the Wehrmacht, 1941 to 1944," in: The Discursive Construction of History: Remembering the Wehrmacht's War of Annihilation, London, 2008.

Ilnytzkyi R., Deutschland und die Ukraine, 1934-1945 Tatsachen europ. Ostpolitik; ein Vorbericht, vol. 2, München, 1955.

Kalba M., "Nakhtigal," in: U lavakh druzhynnykiv: spohady uchasnykiv (Material zibrav i vporiadkuvav M. Kal'ba), Denver, 1982.

Kalba M. (ed.), «Nakhtihal` (Kurin' Dun) u svitli faktiv i dokumentiv, Denver, 1984.

Kurowski F., Baulehr-Bataillon 800 z.b.V. Brandenburg: Akce německých komand 1939-1945, Praha, 2006.

Lopatynskyi Y., "Hrupa pivnich t. zv. Nakhtigal," Svoboda Ukrainian Daily (15 June 1960), p. 2.

Moroz W., Wowk O. (ed.), Litopys UPA. Nowa serija, vol. 12: Wojenna Okruha UPA „Buh”. Dokumenty i materialy 1943-1952, Knyha 1, Kyiv-Toronto, 2009. 
Motyka G., Ukrainska partyzantka 1942-1960. Działalność Organizacji Ukraińskich Nacjonalistów i Ukraińskiej Powstańczej Armii, Warszawa, 2006.

Musiał B., "Bilder einer Ausstellung. Kritische Anmerkungen zur Wanderausstellung „Vernichtungskrieg. Verbrechen der Wehrmacht 1941 bis 1944,” Vierteljahrshefte Für Zeitgeschichte, 47 (1999), pp. 563-591.

Nakonechnyi Y., „Shoa" u L'vovi, 2nd ed., Lviv, 2006.

Patryliak I., Vijs'kova diial'nist' OUN-B u 1940-1942 rr, Kyiv, 2004.

Orhanizacija ukrajinśkych nacionalistiw i Ukrajinśka powstanśka armija. Fachowyj wysnowok roboczoji hrupy istorykiw pry Uriadowij komisji $z$ wywczennia dijalnosti OUN $i$ UPA, Kyiv, 2005.

Raschhofer H., Der Fall Oberländer, Tübingen, 1962.

Ripley T., The Wehrmacht: the German Army in World War II, 1939-1945, New York, 2003.

Rossoliński-Liebe G., Stepan Bandera. The Life and Afterlife of a Ukrainian Nationalist: Fascism, Genocide, and Cult, Stuttgart, 2014.

Schenk D., Noc morderców: kaźń polskich profesorów we Lwowie i holokaust w Galicji Wschodniej, Kraków, 2011.

Struve K., Deutsche Herrschaft, ukrainischer Nationalismus, antijüdische Gewalt. Der Sommer 1941 in der Westukraine, Berlin, 2015.

Talanchuk K. “"Solovejky» DUNu,” in: U lavakh druzhynnykiv: spohady uchasnykiv (Material zibrav i vporiadkuvav M. Kalba), Denver, 1982.

Torzecki R., Polacy i Ukraińcy. Sprawa ukrainska w czasie II wojny światowej na terenie II Rzeczypospolitej, Warszawa, 1993.

\section{Archival sources}

\section{Архів центру дослідження визвольного Руху}

АЦДВР. Ф. 11. - Т. 30. спогади про Корінця Теодора та його діяльність в УВО, ОУН, батальйонах „Нахтігаль” та „Роланд” за 1927 - 1946 роки.

Центральний державний архів вищих органів влади та управління України (ЦДАВОВ)

Ф. 3833. Краєвий провід (керівництво) Організації українських націоналістів на західноукраїнських землях

On. 1. Спр. 20. Крайовий провід ОУН на $3 У 32$

Галузевий Державний Архів Служби Безпеки України (ГДА СБУ)

Ф. 13. Колекція друкованих видань КГБ УРСР, 1920-1992.

Спр. 372. Т. 38.

Ф. 16. Секретаріат ГПУ-КГБ УРСР, 1930-1991.

Оп.1. Спр. 511.

Ф. 65. Справи оперативного обліку КГБ УРСР

Спр. С. - 7448.

Bundesarchiv-Militärarchiv, Freiburg im Breisgau (BA-MA)

RH 20 - 17 Armeeoberkommandos. Heeresgruppe Süd. A.O.K. 17/ Fuhrungsabteilung

Akt. 276. Tätigkeitsbericht Ic./A.O. Anlage Erlassene Befehle Grunsalzl. Schriftverkehr vom 16.03. - 12.12. 1941.

RH 24 - 49 General Komando XXXXIX. Armeekorps/Gebirgs-Armeekorps

Akt. 14. Krigstagebuch Nr. 3 des XXXXIX. (Geb.) A.K. Anlagen II/1 - II/250 


\section{RH 28 - 1 Gebirgsdivisionen}

Akt. 23. 1. Gebirgsdivision, Ia zum K.T.B. Ost. Nr. 1. vom 19.4.-10.8.1941

Bundesarchiv, Berlin-Lichterfelde (BA-BL)

R 43 - II. Reichskanzlei

Akt. 1500. Reichskanzlei. Dr. Lammers.

Mykola Balaban, deputy head of the Center for Strategic Communication and Information Security (Ukraine). Doctoral candidate in history at the Ukrainian Catholic University, research topic: A Micro-History of Violence: Lviv During First Two Weeks of the German-Soviet War (June 22 to July 5, 1944).

(mukola.balaban@gmail.com)

Submitted 04.09.2020, accepted 17.03.2021 